\title{
GCU
}

Glasgow Caledonian

University

University for the Common Good

\section{The discursive governance of forced-migration management: the Turkish shift from reticence to activism in Asia}

Korkut, Umut

Published in:

Journal of Refugee Studies

DOI:

$10.1093 / \mathrm{jrs} / \mathrm{fey} 053$

Publication date:

2018

Document Version

Author accepted manuscript

Link to publication in ResearchOnline

Citation for published version (Harvard):

Korkut, U 2018, 'The discursive governance of forced-migration management: the Turkish shift from reticence to activism in Asia', Journal of Refugee Studies, vol. 32, no. 4, pp. 664-682. https://doi.org/10.1093/jrs/fey053

\section{General rights}

Copyright and moral rights for the publications made accessible in the public portal are retained by the authors and/or other copyright owners and it is a condition of accessing publications that users recognise and abide by the legal requirements associated with these rights.

Take down policy

If you believe that this document breaches copyright please view our takedown policy at https://edshare.gcu.ac.uk/id/eprint/5179 for details of how to contact us. 


\section{Narratives, Audiences, and Geographies of Humanitarianism:}

\section{The Turkish involvement in Syrian and Rohingya refugee crises}

This article shows how similar humanitarian narratives of states can travel across different geographies in response to refugee crises. Empirically, it follows Turkey's position vis-à-vis the Syrian and Rohingya refugee crises. Considering Turkey's migration management practices, humanitarian activism narrative, and its political ambition to foster domestic and international audiences for this narrative, this article elaborates on how Turkey has become a humanitarian actor responding both to Syrian and the Rohingya crises. In both cases, the Turkish political discourses have been very resonant of each other, despite Syria and Myanmar being in different geographies and proximities to Turkey. The article also shows how Turkish politicians and the civil servants aspired to enhance visibility and credibility of Turkey as a humanitarian actor. Delineating Turkey's humanitarian narrative shows the role of political agency in forging sympathetic domestic and international audiences. Overall, the Turkish case presents how states operate migration regimes at the cusp of discourses and institutions affecting their forced migration management and humanitarian engagements.

Keywords: Turkey - Syria - Rohingya - Humanitarianism - Audience making

\section{Introduction:}

This article scrutinizes Turkey's involvement in the management of forced migration since the Syrian refugee crisis has started in 2011. It illustrates that Turkey has assumed humanitarianism, despite maintaining the geographical limitation in its asylum regime to accept only European refugees. ${ }^{1}$ Considering Turkey’s migration management practices, humanitarian activism narrative, and its political ambition to foster domestic and international audiences for this narrative, this article elaborates on how Turkey has become a humanitarian actor responding both to Syrian and the Rohingya crises. In both cases, the Turkish political discourses have been very resonant of each other, despite Syria and Myanmar being in different geographies and proximities to Turkey. Using these crises, the incumbent politicians and the civil servants aspired to enhance visibility and credibility of Turkey as a humanitarian

\footnotetext{
${ }^{1}$ Turkey retains a geographic limitation to its ratification of the 1951 U.N. Convention on the Status of Refugees ("Refugee Convention"), which means that only those fleeing as a consequence of "events occurring in Europe" can be given refugee status (for a further discussion see Kır 2017).
} 
actor. Particularly, the Syrian crisis led to the formation of a new Turkish forced migration management narrative while having also allowed Turkey to engage with forced migration beyond its neighbourhood. Delineating this narrative shows the role of political agency in forging sympathetic domestic and international audiences and the operation of multiple regimes at the cusp of discourses and institutions affecting forced migration management.

To depict political narratives, the article follows slogans - defined by political- and policy-actors themselves as "creative" - such as "historical and religious responsibilities of the Turkish nation" and "the need to continue with "what has always been the case' with Turkish state traditions". These responsibilities and traditions sometimes predate the Republic and reflect on the Ottoman past, but attempt to justify Turkey's recent migration politics, humanitarian diplomacy and garner political support for involvement and activism in forced migration management in near abroad and beyond. Though mainly for domestic consumption, faith-based explanation of such involvement with refugees (Ager and Ager 2011; Ferris 2011; Fiddian-Qasmiyeh 2011; Wilson 2011; Zaman 2016) is also noteworthy insomuch as they resonate in humanitarian roles and narratives of politicians.

Theoretically, this article argues that similar humanitarian discourses can travel across space regardless of the geographical proximity of the refugee crisis to the humanitarian actor. Referring to recent work in securitization theory (Côté 2016), the article foregrounds the importance of audience affecting political agents' intersubjective construction of humanitarian values. The logic of communication as to how actors engage in processes of generating, deliberating, and legitimising ideas of political action in diverse contexts has featured in earlier research (Schmidt 2010). Research on professional discourse indicated that discourse and discursive content 
could travel across situations (Linell 1998). Furthermore, explaining the emergence of new humanitarian actors, particularly using the South-to-South co-operation and Islamic faith-based humanitarianism, and tracing common frames of humanitarian engagement in this regard, have been central to recent research (Pacitto and FiddianQasmiyeh 2013). Moving on from earlier research, this article traces how politicians can endorse humanitarianism in an effort to appeal to both domestic and international audiences. Sometimes, their appeal to domestic and international audiences also acts in confluence. However, my argument is that this appeal is a means to harness political support in domestic sphere and visibility in international sphere as a global actor standing by the aggrieved, oppressed and the victims.

In order to develop this conceptual argument, empirically the paper traces how the AKP politicians such as Ahmet Davutoğlu (2009-2014 Foreign Minister and 2014-2016 Prime Minister), Mevlüt Çavuşoğlu (Foreign Minister 2015 -), and the President Tayyip Erdoğan introduced discursive and material tools to respond to the needs of "aggrieved nations" (mazlum halk). The statements of Mevlüt Çavuşoğlu noted below resemble those of Davutoğlu. While pre-AKP Turkish domestic and foreign policies have been influenced by non-interference and respect for sovereignty (Woods and Sazak 2016) in near abroad (with the exception of Cyprus in 1974), Turkey's foreign policy and line of geopolitical thought under AKP marked discontinuity with the previous era (Aras 2015). To this extent, the article follows narratives with references to Turkey's Ottoman past to qualify the current compassion for aggrieved nations, but also notes that these narratives have not translated in substantial legal change in asylum and integration procedures. Protection is temporary, and primarily for Syrians. 
A further indication of how the narrative of compassion is selective is the infringement of procedural rights of refugees returned to Turkey, following the Turkey-EU Statement and the Greek State Council approving Turkey as a safe third country. Ulusoy and Battjes (2017) point at violations of the principle of nonrefoulement, arbitrary detention and risk of deportation of refugees to their country of origin without juridical review - effectively undermining the international protection mechanism. Hence, the empirical and theoretical debate in this article indicates that Turkey's reframing of responsibility in forced migration management relies on broad narratives. Turkey's refugee protection both internally and externally depends on the humanitarian actor image that the Turkish governments seek to present to international and domestic audiences. Yet, policy change to facilitate comprehensive protection and integration of refugees at home is limited even if one can refer to ongoing institutionalisation of Directorate of Migration Management as a positive step.

\section{Turkey as a humanitarian actor: Pro-activism and Inconsistencies}

While originally studying Turkish responses to the Syrian refugee crisis from 2014 onward for an earlier project, I came across a deliberate and discursive making of Turkey as a humanitarian actor. During an interview at the Turkish Delegation to the UN in August 2014, my interviewee, a Turkish diplomat, pointed at the continuity in Turkish migration politics from the Syrian to the Rohingya crises. The interviewee stated that the Turkish involvement in Syrian refugee protection made Turkey a "proactive" state in contributing to refugee policies at the international level. Indeed, the "humanitarian diplomacy" narrative of the ex-Prime Minister Davutoğlu (2013) has gained strategic relevance for a series of global issues in Turkey's international 
relations. According to Davutoğlu (2013), humanitarian diplomacy means that Turkey's influence is to be felt over a wide geographical area, not only symbolizing its power but also symbolizing its conscience. This influence

[i]s based on a critical equilibrium between conscience and power. In this equation, if a state has conscience but no power, it shows weakness. If it has power but no conscience, it becomes a tyranny. Our idea is for Turkey to be a compassionate and powerful state. One will be compassionate if one's conscience dictates where one should go and to whom one should reach, as can be seen from the examples of our aid to Somalia and Syrian refugees. At the same time, one will need to have power, so that one has the ability to reach where needed (Davutoğlu, 2013: 867).

Reflecting particularly on the Turkish protection of Syrian refugees, Davutoğlu suggested that " $[w]$ e do all these with a sense of high responsibility as we regard our Syrian neighbours as our brothers and sisters with whom we share long history and often a common fate" (MFA 2012).

For Davutoğlu, the tools of humanitarian diplomacy were to be Turkish Airlines, TIKA (Turkish International Cooperation and Coordination Agency), NGOs, Kızlay (Turkish Red Crescent), and TOKI (Housing Development Administration of Turkey), as well as the state apparatus acting in coordination to support Turkey's power and ability to assist people (Davutoğlu, 2013). This is in line with what Davutoğlu (2001) has introduced earlier that his country's identity is the product of its distinctive history and regional specificities, and that these contexts provide it with unique assets. And it is maintained that, due to Turkey's presence in several geocultural spheres (including the Balkans, the Middle East, and Europe), Turkey has no choice but to be innovative and active as a policy leader and globalization visionary (Bayer and Keyman 2012: 74).

Despite humanitarian diplomacy gaining credibility, AKP governments avoided introducing policy changes in effect to increased protection and integration of refugees. As noted above, Turkey extends temporary protection to Syrians on its 
territory while other refugees can face removal and exclusion from humanitarian protection as per the 2016 Law on Foreigners and International Protection. An adverse public philosophy on receiving migrants (Ikizoglu Erensu and Kaşlı 2017, Deutsche Welle 2015) or Turkish governments' seeking to avoid financial implications of an institutionalised protection and integration regime could explain continued restrictions. At 2016 World Humanitarian Forum in Istanbul, Erdoğan stated that Turkey's development aid has reached 6.4 million USD. To finance this engagement, Gilley (2015: 45) noted that up to 75\% of Turkey's spending on major crises came not from budgetary allocations, but from government-organized telethons. This shows the importance of fostering amenable audiences to foster humanitarian diplomacy and encouraging a globalist Islamic sensibility (Gilley 2015: 42; also see Parlar Dal and Oğuz Gök 2014, Kösebalaban 2014). Through its global engagement the AKP government also appeals to the Turkish public, who enjoys the strong leadership profile of Erdoğan in global peace and conflict matters (Özerdem 2015: 72), including Somalia (Tank 2015). That is why, Erdoğan pays importance to humanitarian assistance while foregrounding domestic themes such as ancestors, martyrs, and conscience.

One of the elements of progress that Turkey has achieved in the past 13 years (since the inception of AKP governments) is humanitarian assistance. While in 2002, we were getting a hand, in 2015 we are giving hand. We assist over 140 countries in various fields. We are the third most generous country in the world. [...] While we do not have any oil, we have as large conscience as Anatolia. We host 2.5 million who sought shelter to save their lives (in reference to Syrians). The amount of money we have spent for refugees is 9 billion dollars. We received 417 million in aid from foreign states. We received dollars as remedy, but we did not receive conscience as remedy. We carried on with expanding our humanity and compassion. We are such a civilisation that we know the value of sharing. We are members of a civilisation that would shame going to bed with full stomach if our neighbours are famished. For some this may not be worthy, 
but our goal is to make those people stand on their feet again if our ancestors (ecdad) became martyrs over there (T24 2015).

AKP inculcates a narrative for standing by the oppressed and aggrieved nations in order to foster audiences amenable to its politics at home. According to an interviewee quoted in Özerdem's study “through running large-scale humanitarian programmes such as the one in Somalia, Turkey has become aware of its power" (2015: 72). What matters also for the domestic audience is the expanse of geographical space within which Turkey's humanitarian narrative resonates.

Methodology and the organisation of the paper:

In order to spell out the discourses that contain Turkey's humanitarian narrative, I follow Jørgensen and Phillips' (2002) assessment that language is not neutral and discourse should be empirically analysed within its social context. However, following Leudar and Nekvapil (2004: 247) that "media texts are addressed not to a specific person or sets of persons with known properties, relevancies and beliefs, but rather to a public at large", I consider the domestic and international public spheres as social contexts, and de-emphasize the immediate geographical contextual factors affecting politicians' framing of refugee issues. This is due to my observation that the politicians formulate their discourses not for their immediate audience, but for consumption by the general public, being sure of the role that the media will play in their subsequent dissemination (See Lu, Aldrich and Shi 2014 for China). To depict the unfolding of forced migration management by Turkey and its role in effect to two refugee crises, the paper follows discursive governance framework. Essentially, discursive governance refers to implicit mechanisms of governance resting on narratives, leitmotifs and strategic metaphors in political 
language, and the subsequent framing of policies using this language to interpose ideas and mark political and social representations within the public sphere in accordance with the wishes of political authorities (Korkut et. al. 2015).

Empirically, the paper traces the discourses used by the AKP government to forge audiences. I resort to interviews to display the slogans and discourses while studying the Syrian crisis in different levels and locations of Turkish public administration, namely, in Ankara, Southeastern Turkey and the UN Delegation in New York in 2014. For the case of Rohingya, I explore media narratives using keywords such as "Turkey and Aceh”, “Turkey and migration diplomacy”, Turkey and Rohingya", as well as "Turkey and Myanmar" and other countries in the region. The variation in research methods is due to my interest in understanding and explaining how discursive representation functions using various means. Under the theoretical guidance of dialogical research tradition, the paper "is concerned not only with the processes by which people creatively rework social knowledge to develop their positions, but also the movements of such knowledge between the everyday communicative public sphere of reasoning and debate, and the coordinative public sphere of social actors" (Mahendran 2012: 64). The interview environment as well as the media provides types of "everyday communicative public spheres" to witness how the members of the public are influenced by hegemonic representations (Moscovici 1984) and politicians setting the terms of debate. Thereby, this article pursues the impact of narratives on the intersubjective construction of humanitarian values within domestic and international audiences looking at political narratives and slogans, political and policy discourses, newspaper reporting, and dialogical reflections on collective memory and social identities. 


\section{The Syrian Case: The making of "extraterritorial brotherhood"}

The arrival of refugees commenced with the crossing of about 250 Syrians into Turkey’s Hatay province towards the end of April 2011. Following this instance, the then Turkish Foreign Minister Ahmet Davutoğlu announced that Turkey was ready to allow in those Syrians 'who are not happy at home', and this effectively unleashed the open-door policy for Syrians initially escaping the clashes between the government and the opposition (Ilgit and Davis 2013) and latterly escaping the clashes between various militant groups. In March 2012, Erdoğan appealed to the UN to establish a 'safe haven' inside Syria for Syrians facing 'humanitarian disaster' (Ilgit and Davis 2013) demonstrating Turkey's humanitarianism to an international audience. Turkey has increasingly been involved in a major humanitarian effort to accommodate large numbers of refugees. According to 2018 figures provided by the Turkish Government, there are more than 3.5 million registered Syrian refugees in Turkey (Syria Regional Refugee Response 2018). While almost a quarter of Syrians live in refugee camps, the rest have been dispersed all around Turkey, living in temporary accommodation and involved in informal employment.

Since the initiation of the Syrian refugee crisis, the AKP has delineated the victims of the war in Syria as merely Sunnite Muslims and in so doing politically engaged with the Syrian crisis as an active supporter of the Sunnite forces in Syrian opposition (Han 2013; Gürsel 2012; Hinnebusch and Tür 2013). This deliberate narration of the crisis as a war between the Sunnite victim and the Alawite oppressor sought to justify to the domestic audience Turkey's involvement in Syrian refugee crisis. It also aimed at preventing a possible reaction from the public, given its prevalent averseness to foreigners (Ikizoglu Erensu and Kaşlı 2017), which one can 
qualify as aversion to difference and lack of empathy with the external as well as the internal other (Korkut 2014).

Effectively, the President Erdoğan's and the Prime Minister Davutoğlu's statements have set the terms of public narratives regarding the Syrian refugees. Though never a part of policy language, Erdoğan introduced the metaphor ensar to qualify the role that Turks should play for Syrians in Turkey (Korkut 2016). Ensar refers to the people of al-Medina, who supported the Muslims who immigrated there from Makah facing persecution from the non-believers. In essence, this pointed at a temporary situation - as the Muslims returned to Makah when their forces recaptured the city from the pagans, and depicted the persecutor Alawite Assad as non-believer. The President Erdoğan introduced the ensar metaphor while addressing Syrians in Gaziantep immediately after his election to office in 2014. After voicing his hopes that conditions would improve in Syria as soon as possible, so that the guests could return their homes, he reminded his audience that "we in Turkey have been pleased and deservedly proud of hosting you here for nearly four years ... we have one-and-ahalf million of our brethren as guests" (Haber 7 2014). I consider the use of this metaphor essential to our understanding of the references that interviewees gave to the generosity of the Turkish nation that I will present below. These references follow the humanitarian diplomacy discourse displayed above and qualify further responding to aggrieved nations including Syrians and Rohingya Muslims.

In legal terms, however, what sets the Syrian refugees distinct from other refugees in the country is their "temporary protection" in Turkey. The principles of temporary protection are such that Turkey will maintain an open border policy' for all Syrians, and it will respect their non-refoulement on condition that they register with the Turkish authorities. The policy includes renewable but unlimited stay, protection 
against forcible returns, and access to reception arrangements where immediate needs are addressed (Korkut 2016). The introduction of the temporary protection and the underlying "our Syrian guests" narrative not only illustrates the operation of a pragmatic operationalization of humanitarianism, but also its selectiveness. As further supportive slogans show below, on the one hand, the operation of guest narrative appeals to the collective memory - as qualified by Halbswach (1992), Maines, Sugrue, and Katovich (1983) and Schwartz, Zerubavel, and Barnett (1986) - of the Turkish public, and promotes Turkey as a charitable polity with a responsibility for people from its imperial past. On the other, the selective application of protection shows that it is the innate characteristics of incomers that qualify them for the degree of reception and protection rather than a comprehensive humanitarian approach toward refugees in Turkey. Rather than formal institutionalization of humanitarianism, therefore, what we see is the state authorities' narrative-setting to justify Turkey's temporary involvement and moral responsibility merely to Syrians. Below, I list some slogans that I came across in my interviews with the civil servants that are decision makers at the central and local levels for Syrian refugees.

Turkey's Disaster and Emergency Management Presidency (AFAD) has been the most active agency with respect to the Syrian refugee crisis. AFAD serves under the Prime Minister's Office enabling it to be both in charge of policy setting and have direct access to resources to deal with refugee issues. I held interviews respectively in February 2014 and May 2014 both at Ankara headquarters and the Gaziantep branch office of AFAD. In order to verify what I heard in these interviews, I followed them on with subsequent interviewees at the IOM office in Ankara and the K1z1lay (Turkish Red Crescent) Headquarters. The AFAD officials framed Syrians' presence in Turkey with the Turkey being a "charitable polity" and the Turkish people being "strangely 
unique in terms of assistance". In Ankara, AFAD interviewee reflected on "how things have been and always are" in Turkey and within the Turkish society in order to emphasize the charitable characteristics of the Turkish polity. The AFAD official in Gaziantep regional branch, however, expressed that the Syrians were the guests of the state ("not ours, but the state's"), and they would go back when the state tells them to leave. However, until that eventuality, as the interviewee underlined, the state was committed to pay for their expenses.

Thereby, in Gaziantep close to the Syrian border the discourse was rather problem-focused. The then Regional Governor with responsibility for the Syrian refugees also reiterated the responsibility of the Turkish state and the public but also listed the problems that long-term needs of the Syrians were posing in Southeastern Turkey (Interview with the Regional Governor for Refugee issues in Gaziantep, May 2014). In Ankara, however, general humanitarian narratives were more common resonating also at the interviews with the Turkish MFA and Ministry of Labour. The interviewees indicated "ample economic means of the Turkish state" as well as "Turkey is responsible for Syrians, given its imperial past in the Middle East", "If we consider the interrelationship between the Turkish and the Syrian populations perhaps for centuries, there can be no argument for closing the borders for Syrians" (MFA interview 2, Ankara, February 2014; ML focus group interview, Ankara, February 2014); and "The Turkish assistance to Syrians is a form of alms giving that Westerners cannot understand" (ML focus group interview, Ankara, February 2014). I consider these slogans as direct derivatives from Davutoğlu's humanitarian diplomacy political discourse displayed above. The divergence between the local and central bureaucracy in terms of how they elaborate on humanitarian diplomacy could show that the regional actors are more realistic than the actors in the capital, who are also 
more likely to serve as the main audience for the political discourse far from political realities that afflict the regions closer to the crisis.

If AFAD has been the most central actor in domestic issues regarding Syrians, the Turkish MFA has been the coordinator of the Turkish humanitarian efforts in collaboration with international actors. Their role implied that "[They operate] in the name of the international community; this is a problem of international community. When Turkey assumes responsibility, it is decreasing the extent of the burden [that the Syrian refugees pose] on the international community" (MFA interview 1, Ankara, February 2014). As I showed above, the responsibility for refugees, assumed in the name of the international community, came out also in Erdoğan's speech at the UN. Acting on behalf of the international community; hence, the responsibility narrative is an indication of how Turkey sought to appeal to international audiences while having engaged with humanitarianism within its immediate neighbourhood.

Overall, the narration of Turkey's role vis-à-vis the Syrian refugees illustrated how political and policy actors have attempted to affect the domestic and international audiences. Ample referencing to "how things have always been with us" has been the main tool of collective memory generation. I argue that these provide the discursive tools to frame the Syrian refugees as 'guests' for domestic audiences sphere while underrating what could be the troubling essence of hosting refugees. It is also that those refugees that deserve consideration are the ones framed as Turkey's 'relatives' and 'religious brothers'. In this case what affects assistance is historical and moral responsibility, and its temporality rather than a comprehensive humanitarianism per se. Yet, there is also an attempt to appeal to international audiences with an emphasis on humanitarian diplomacy and Turkey as a humanitarian actor. While the implication of generating amenable international audiences has so far been studied 
with respect to material gains (inter alia Korkut and Civelekoğlu 2013), there is also recent research that qualifies an activist role for Turkish foreign policy (Civelekoglu and Yan1k forthcoming) as populist insomuch as it consolidates a "geography of the oppressed" between the domestic and the external. The 2018 general election result also shows that to an extent that AKP could present itself as an actor defending the global oppressed, it consolidates its voter base at home. Let us see how AKP's involvement in a refugee crisis far from Turkey's immediate borders also serve similar function.

\section{The Case of Rohingya: The Turkish Discovery of "Muslims" in Southeast Asia}

The 2004 earthquake and tsunami disaster in Southeast Asia became the harbinger of news in Turkey about the imaginary fellow Muslim in Southeast Asia that followed the Ottoman Caliph and even collected money to help the Republic during its fight with the invading western powers from 1919-1922. The then AKP Minister of Foreign Affairs, Abdullah Gül, stated, "Banda Aceh has had a relationship with us since the period of Ottoman Empire. They also helped us during the 'War of Independence' [The 1919-1922 War in Anatolia officially called in Turkish]” (Radikal 2005). Subsequently, a parliamentary committee convened to discuss the possible forms of emergency aid and reconstruction in the area, and visits to the region by the committee and the then Prime Minister Erdoğan followed. The AKP government delegated the handling of emergency relief and assistance to the region to AFAD, Kizilay, as well as some NGOs (Records of Parliamentary debates, 3.02.2005). The Turkish involvement in Banda Aceh also served to showcase the role that AFAD was to play later as a party to Turkey's humanitarian diplomacy. 
Similar to the Syrians, in time, AKP has foregrounded the 'historical relationship' between Turkey and various Muslim minorities in Southeast Asian states such as Southern Thailand and Vietnam. The following involvement of AKP governments with the Rohingya people of Myanmar has been an extension to, what the Turkish Ambassador to Naypyidaw called, the "Turkish Opening to Southeast Asia" (haberler.com 2013). Extensive destruction of homes and damages of other properties in the predominantly Muslim-populated coastal area of the Rakhine state triggered the ongoing refugee crisis of the Rohingya Muslims culminating in mass expulsion in late 2017. The rights group urged the Myanmar government to take the necessary measures to end violence against the Muslim population and for the arrangement of adequate security. Earlier Human Rights Watch documented targeted killings, rape and mass arrest of Rohingyas by the Myanmar security forces. The report condemned authorities for imposing restrictions on humanitarian access to the Rohingya community, who were in dire need of food, shelter and medical care (Human Rights Watch 2012 in Kipgen 2013: 305). The most recent reports indicate ethnic cleansing and even methodical massacres carried out by security forces against the Rohingya in Myanmar (Human Right Watch n.d.).

The discursive formulation of the Rohingya, in this context, and the Turkey's obligation to assist them followed the pattern of post-crisis engagement with other extra-territorial Muslims such as Syrians. Yet, the Rohingya was much less known publicly. This required the authorities to cultivate a public narrative that they are fellow Muslims. In order to foreground the religious foundations of Turkey's involvement with the Rohingya, in the Turkish language media outlets - closely associated with AKP - the Rohingya has been consistently called as either the Rohingya Muslims or the Arakan Muslims while the MFA in English language 
statements simply referred to them as the Rohingya. This has become a continuous tendency for MFA accounts of Turkey's relations with the Rohingya. In recounting the latest visit of the Minister of Foreign Affairs Çavuşoğlu to Myanmar, the MFA noted in Turkish that the Minister came together with Muslims from Arakan (MFA 2016a) while in English the account of the trip noted the Minister met with the local communities including Muslims in the Rakhine State (MFA 2016b). Although Rohingya-rights organisations based in Europe do not emphasise their Muslimness, the demarcation between the Rohingya and Rohingya (or Arakan) Muslims remained consistent in MFA's statements in Turkish. Reporting of the visit by the European Rohingya Council to the Minister of Foreign Affairs in August 2015, the Turkish language statement quoted the Minister Mevlüt Çavuşoğlu that they (Turkey or MFA not clear) will continue with their efforts to support the Rohingya Muslims (MFA 2015a). Yet, the press release by the MFA in English in May 2015 drew attention to the "tragedy of thousands of Rohingyas and Bengalis, who were stranded in the Andaman Sea in their boats as they were being taken from Myanmar and Bangladesh to Indonesia and Thailand by human traffickers" without a similar emphasis of their Muslim character (MFA 2015b). This shows that while for the international audience Turkey has attempted to present itself as a universal humanitarian standing by the global aggrieved, for the domestic sphere the Ministry has sought to justify Turkey's involvement in this far away region by framing the Rohingya as Muslims.

Alongside the Aceh Muslims connotation, the government also set a narrative that "Turkey is historically indebted to Rohingya Muslims". The following quotation from an interview with the then Foreign Minister and the current Prime Minister Davutoğlu on TRT (Turkey's public TV) during a government-organized telethon on 17 August 2012 to raise funds for Arakan Muslims supports this inference. 
While we were fighting the War of Independence our brothers from Arakan sent what earned under such dire circumstances to Turkey. In 1917, approximately 12,000 Ottoman soldiers, our ancestors [a term fundamental to AKP politicians' references to the Ottomans - the author], taken as prisoners of war from battle fields in Iraq, Egypt, and Syria, were transferred to Myanmar and placed in camps in Birmania as it was called then. Since opening our Embassy, we presented our Ambassador with two duties that first he would find the grounds that our martyrs have been buried and restore them in order for us to tell our martyrs that we brought you our scarlet flag for which you died for. Essentially when we visited our war graves we realised how historical links [allegedly between Myanmar and Turkey] connect us. The tombstones of our martyrs have been preserved in a mosque nearby. Second, we told our Ambassador that he should see after the fate of Arakan Muslims. Because the Arakans are really aggrieved people [mazlum halk in Turkish ]. While they have been living in those geographies for centuries, right now they do not even have any citizenship. We had to provide for our brothers who lost their homes during the most recent conflicts and permanently solve their problems with building homes for them. For the first time, the government of Myanmar accepted international relief. Our Kizilay and the Red Cross of Myanmar signed a cooperation treaty. We are going to establish a crisis centre in Myanmar [...] Our nation is one with a public spirit. Last year, we organised a campaign in Somalia. Now the whole world talks about the miracle in Somalia. We will act similarly in Arakan [...] As members of a grand nation we are struggling to reach wherever there is pain" (Available at, https://www.youtube.com/watch?v=RE-iZnW-UME. Accessed 17.12.2015).

This long, however, substantial quote from Davutoğlu outlines how Turkey presents its interest and involvement in the fate of Rohingya in Southeast Asia to the domestic audience quite succinctly. Drawing parallels with a similar involvement with Syria, we can underline the common metaphors such as "our ancestors" (ecdad) representing the Ottomans and "the aggrieved people" (mazlum halk) qualifying those that the AKP has declared to stand for both at home and beyond in near abroad or further geographies. As I have indicated above, I consider the slogans, narrative, and metaphors as first tools for collective memory making and second attempts to foster audiences for Turkey's humanitarianism and responsibility for aggrieved nations. In this regard, we can also witness a confluence in the themes of domestic and the international appeal. 
"We owe them so much" (çok büyük borcumuz var onlara) has been a major slogan in circulation, despite its ambiguity due to "them/onlar" in Turkish as a pronoun. This slogan has been in circulation in media outlets close to the AKP government despite this ambiguity regarding whether "them" refers to Arakan Muslims or "them" as the Ottoman Turkish POWs buried in Myanmar. Though deceptive, this slogan has served for the purpose of promoting a relationship to this distant geography in the minds of the domestic audience (Haberturk 2012). The narrative construction of the Rohingya as a distant historical and co-religious acquaintance finds support in the public sphere and among the civil society (Çebi 2017, also see various MAZLUMDER accounts pro-Rohingya civil action in 2012).

Beyond characterising Turkey's involvement with the Rohingya differently for the domestic and international audience, the Turkish officials also made a difference within the international audience and preferred to appeal to those critical of the West. The discourse for both the Syrian and the Rohingya crises emerged initially as critical of the West, but then taken on an increasingly anti-Western tone (Gilley 2015, 52). The criticism of the West in both occasions, arguably, relates to the government's efforts to showcase itself as a defender of aggrieved nations and an international actor more conscientious than the West to the domestic and international audiences. Earlier studies also showed how non-Western and emerging powers utilise humanitarian assistance as a priority "because it fits well with their active diplomatic agendas that seek to increase influence through such good international citizenship" (Gilley 2015: 47; Binder and Meier 2011). However, in the case of Turkey, this also implied an appeal to generate pro-government domestic audience affected by how the government stands by the oppressed. The underestimation of the West and foregrounding the leadership role that Turkey plays presents the capacity that the state 
has gained as a regional leader and contribute to how the AKP wishes to present

Turkey as a global crisis solver. The discursive construction of the leadership role that

Turkey vies to play is evident in following excerpts from the media.

\begin{tabular}{|l|l|}
\hline Discourse & Source \\
\hline $\begin{array}{l}\text { "The President Erdoğan indicated to the Prime Minister of Malaysia that Turkey is } \\
\text { ready to bear its share of burden [in assisting the Rohingya], however, along with } \\
\text { delivering aid, the refugees should be taken care of once they reach land [as they are } \\
\text { momentarily in Andaman Sea]" }\end{array}$ & NTV (2015) \\
\hline $\begin{array}{l}\text { "[The] Turkish Foreign Minister Mevlut Cavusoglu has offered assistance to Malaysia } \\
\text { and Indonesia in building settlement centres for [the] Rohingya Muslims [...] and } \\
\text { provide material and technical support for infrastructure" }\end{array}$ & TRT (n.d.) \\
\hline $\begin{array}{l}\text { "[The] President Recep Tayyip Erdoğan called [the] Malaysian Prime Minister [...] to } \\
\text { talk on refugees stranded in the Andaman Sea and confirmed that Turkey was ready to } \\
\text { take responsibility on the issue" }\end{array}$ & $\begin{array}{l}\text { (Hurriyet } \\
2015 a)\end{array}$ \\
\hline $\begin{array}{l}\text { "Turkey was doing its best to reach Rohingya Muslims at sea with IOM, with the help } \\
\text { of a ship from the Turkish Armed Forces already sailing in the region" }\end{array}$ & $\begin{array}{l}\text { (Hurriyet } \\
2015 a)\end{array}$ \\
\hline $\begin{array}{l}\text { "Turkey's Foreign Minister Mevlüt Çavuşoğlu said Ankara would have sheltered the } \\
\text { Muslim Rohingya and Bangladeshi migrants with merchant ships close to the } \\
\text { Andaman Sea if Indonesia and Malaysia had not }\end{array}$ & $\begin{array}{l}\text { (Hurriyet } \\
2015 b)\end{array}$ \\
\hline $\begin{array}{l}\text { "The Director General of Religious Affairs [Diyanet] Görmez, both the Turkish } \\
\text { nation as well as the Directorate General of Religious Affairs are doing their best to } \\
\text { solve the difficulties of the Rohingya Muslims"; "Insomuch as the persecution in the } \\
\text { region continues, Turkish nation will feel for Arakan Muslims"; "Vakar Uddin [The } \\
\text { President of Arakan Rohingya Council] said that having Turkey right beside them } \\
\text { fosters their confidence [...] Their situation became globally known thanks to the } \\
\text { efforts of Turkey" }\end{array}$ & $\begin{array}{l}\text { Anadolu } \\
\text { (2014) }\end{array}$ \\
\hline $\begin{array}{l}\text { "The leader of Rohingya Solidarity Organisation Muhammed Yunus stated, Only } \\
\text { Turkey paid attention to us. When Davutoğlu came to Arakan we cried for the first } \\
\text { time with happiness" }\end{array}$ & $\begin{array}{l}\text { (Camiye.com } \\
\text { n.d.) }\end{array}$ \\
\hline
\end{tabular}

The leadership narrative may target the Turkish audience since the assistance that

Indonesia and Malaysia may have given to Rohingya does not receive much emphasis

in news reporting. These two regional powers appear as passive actors to which either

Turkey offers assistance or designates responsibility in Turkish language sources.

Hence, Turkey appears at the centre of all efforts to help the Rohingya insomuch as it

contribute to and collaborates with international migration agencies, namely IOM and

UNHCR, takes the Rohingya issue to OIC, and sends its navy to protect the Rohingya

and deliver relief.

Overall, Turkey has been an active narrative setter in humanitarian assistance

to Rohingya even if it promised a mere sum of 1 million dollars. To affect the 
international audience the government had been keen to emphasize its collaboration with IOM, UNHCR, and OIC, and regional partners such as Indonesia and Malaysia (IOM 2014, IOM 2015, MFA 2015b). To have an impact on the domestic audience, however, they emphasise leadership, responsibility and charity under the leitmotif of "Rohingya Muslims" and foreground Turkey's leadership. In this context, the only news item reminding the public that the Rohingya in fact may need protection and resettlement, rather than the public narratives and any meagre sum of relief, has been the one stating that "the Gambian government declared that it is their sacred duty to accept the Arakan Muslims and host them in refugee camps" (NTV 2015).

\section{Conclusion:}

AKP has led the Turkish migration politics guided by a discursive framework that aims to appeal to and garner domestic and international support. The operation of this framework generates respective audiences in support of Turkey's humanitarianism, but falls short of initiating substantial institutional changes in Turkey's refugee policies. Therefore, when studying forced migration, we need to take into account modes of discursive regimes that political authorities may pragmatically utilize. Social representations (Moscovici 1984) of Turkey’s humanitarianism, the government's humanitarian diplomacy, Turkey's leadership, the "deserving refugees", the Turkish history, but eventually the preservation of the geographical limitation in Turkey's asylum contribute to the making of multiplicity of regimes at the intersection of institutional and discursive systems. To this extent, the article followed how discourses in the form of public narratives foster and affect audiences (Mahendran, Jackson, and Kapoor 2015), and bolster strategically manipulated identities and a co-operative collective memory (Halbswach 1992; 
Maines, Sugrue, and Katovich1983; Schwartz, Zerubavel, and Barnett 1986), and noted how Turkey has still maintained restrictive protection and limited integration policies. My argument is that garnering support with discourses gives a free hand to states to operate their migration politics selectively rather than introducing a full overhaul of migration and humanitarian policies. What matters then is not the needs of migrants, but what the governments safely need to represent their actions following a self-made humanitarian narrative.

In the end, this paper presents an overview of the everyday communication and audiences that AKP has sought to justify Turkey's humanitarianism at its borders and beyond. It followed the narratives and slogans central to everyday communication with interviews with policy actors, official statements, and their reporting in newspapers. By underlining the AKP governments' narrative of humanitarian diplomacy, the empirical debate of this paper referred to how the Syrian crisis has led to the formulation of the Turkish forced migration regime and how this regime opened space for Turkey to further engage with forced migration beyond its borders. However, I also argued that engagement in humanitarian crises has become instrumental for fostering narratives and even a populist foreign policy (Civelekoğlu and Yanık forthcoming). In this sense, ad hoc discourses qualified "the Syrians as guests and brothers" and "the Rohingyas as an aggrieved nation that has been fellow Muslims" circulated within the domestic and international audiences. The implication has been that Turkey has a responsibility for these nations given its history, collective memory, leadership potential, and humanitarian operations capacity distinct from the west.

The literature on forced migration notes that states do not follow their institutional systems for accepting refugees once migration regimes are securitized 
(c.f. see Landau and Amit 2014 on South Africa). However, the forced migration management that the Turkish case represents shows a space where politicians could configure, transmit, and initiate politics ideationally, rather than vouchsafing substantial policy change in effect to governance towards a comprehensive policy change in the asylum regime. Hence, along with discourses precluding the functioning of institutions, discourses can function as institutions in their limited presence. However, this brings forth selectivism and temporality as Turkey's involvement with the Syrian and Rohingya refugee crises showed. Syrians are marked as a 'guest' that needs protection. The Rohingya is marked as a fellow Muslim whose relief requires Turkey's care and leadership. However, in general migrants remain a threat for a generally foreignness averse public (Ikizoglu Erensu and Kaşlı 2017; Korkut 2014). In this context, geography remains instrumental to Turkey's humanitarian engagement insomuch as it assists the AKP government's appeal for both at domestic and international audiences to depict Turkey and its politicians as conscientious global actor. 
References:

Ager, A. and Ager, J. (2011) "Faith and the Discourse of Secular Humanitarianism". Journal of Refugee Studies 24(3): 456-472.

AKP (2011) Available at, https://www.akparti.org.tr/site/haberler/suriye-meselesibizim-ic-meselemizdir/11521\#1. (Accessed 2 December 2015).

Anadolu Ajansi (2014). "Rohingya Müslümanları için her türlü gayreti gösteriyoruz", available at, http://aa.com.tr/tr/turkiye/rohingya-muslumanlari-icin-her-turlugayreti-gosteriyoruz/175012. Accessed 18.12.2015.

_ (2015). "Rohingya in Turkey determined to help those back home", available at, http://aa.com.tr/en/world/rohingya-in-turkey-determined-to-help-those-backhome/41982. Accessed 18.12.2015.

(2011) "Turkish Premier Visits Somali Camp", 19 August 2011.

Aras, B. (2015) Reform and Capacity Building in the Turkish Foreign Ministry: Bridging the Gap between Ideas and Institutions 17: 269-285.

Bayer, R. and Keyman, F. (2012). "Turkey: An Emerging Hub of Globalization and Internationalist Humanitarian Actor?", Globalizations 9(1): 73-90.

Binder, A. and Meier, C. (2011). "Opportunity Knocks: Why Non-Western Donors Enter Humanitarianism and How to Make the Best of It", International Review of the Red Cross, Vol. 93(884):

Camiye (n.d.) "Rohingya Dayanışma Örgütü Başkanı Yunus, "Bizi bir tek Türkiye önemsedi. Davutoğlu Arakan'a geldiğinde ilk kez mutluluktan ağladık" dedi”, available at, http://www.camiye.com/?Syf=18\&Hbr=532867\&/RohingyaDayanıșma-Örgütü-Bașkan1-Yunus,-Bizi-bir-tek-Türkiye-önemsedi.Davutoğlu-Arakana-geldiğinde-ilk-kez-mutluluktan-ağladık-dedi. Accessed 17.12.2015.

Çebi, E. (2017) Myanmar'ın Rohingya Çıkmazı, available at, http://insamer.com/rsm/files/Myanmarin\%20Rohingya\%20CikmaziArakanda\%20Tarihi\%20Surec\%2C\%20Ic\%20Dinamikler\%20ve\%20Uluslara rasi\%20Aktorler.pdf.

Civelekoğlu, I. and Yanık, L. (forthcoming). "Matrushka Populism(s)?: Turkey and the Making of the Geography of the Oppressed (Mazlum).

Côté, A. (2016). "Agents without agency: Assessing the role of audience in securitization theory", Security Dialogue 47: 541-558.

Davutoğlu, A. (2013). "Turkey's humanitarian diplomacy: objectives, challenges and prospects". Nationalities Papers: The Journal of Nationalism and Ethnicity 41(6), 865-870.

Deutsche Welle (2015) "Suriyelilere tepki büyüyor", available at, http://www.dw.com/tr/suriyelilere-tepki-büyüyor/a-18475031 (May) Accessed 29.06.2017.

Ferris, E. (2011). "Faith and Humanitarianism: It's Complicated" Journal of Refugee Studies 24(3): 606-619.

Fiddian-Qasmiyeh, E. (2011) "Introduction: Faith-based Humanitarianism in Contexts of Forced Displacement", Journal of Refugee Studies 24: 429-439.

Gilley, B. (2015). "Turkey, Middle Powers, and the New Humanitarianism", Perceptions XX(1): 37-58.

Government of the Republic of the Union of Myanmar (2012). Press Release in Response to a Documentary Programme of Al-Jazeera TV, (6 December).

Gürsel, K. (2012). “Milletin meselesi nasil milli mesele olur?” Milliyet, 28 June. 
Human Rights Watch (2012). "Burma: New Violence in Arakan State" (27 October), available at, http://www.hrw.org/news/2012/10/26/burma-new-violencearakan-state. Accessed 16.12.2012.

Jørgensen, M. W., and L.J. Phillips. Discourse analysis as theory and method. Sage, 2002.

Han, A. K. (2013). "Paradise Lost: A Neoclassical Realist Analysis of Turkish Foreign Policy and the Case of Turkish-Syrian Relations" Turkey-Syria Relations. Between Enmity and Amity. In R. Hinnebusch \& Ö. Tür (Eds.): 5570, Aldershot: Ashgate.

Haber 7 (2014). "Cumhurbaşkanı Erdoğan: Bizler Ensar sizler muhacir”, 07 October, available at, http://www.haber7.com/ic-politika/haber/1208342cumhurbaskani-erdogan-bizler-ensar-sizler-muhacir. Accessed 31.03.2016.

Haberler.com. (2013). "Naypidav Büyükelçisi Ateş, Türkiye Myanmar İlişkilerini Değerlendirdi”, available at, http://www.haberler.com/naypidav-buyukelcisiates-turkiye-myanmar-5329136-haberi/.\%20Accessed\%2017.12.2015. Accessed 18.12.2015.

Hinnebusch, R., \& Tür, Ö. (Eds.). (2013). Turkey-Syria Relations. Between Enmity and Amity. Aldershot: Ashgate.

Human Rights Watch (n.d.) Rohingya Crisis, available at, https://www.hrw.org/tag/rohingya-crisis.

Hurriyet (2015a). "After sending ship, Turkey to donate \$1 million for Rohingya refugees", available at, http://www.hurriyetdailynews.com/after-sending-shipturkey-to-donate-1-million-for-rohingya-

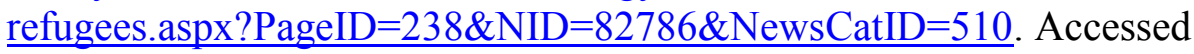
17.12.2015.

Hurriyet (2015b). "Turkish FM says Ankara 'would have sheltered Rohingya", available at, http://www.hurriyetdailynews.com/turkish-fm-says-ankarawould-have-shelteredrohingya.aspx?pageID $=238 \& n I D=83209 \& N e w s C a t I D=510$. Accessed 17.12.2015.

Hurriyet Daily News (2015). "173 Uighur refugees arrive in Turkey from Thailand", available at, http://www.hurriyetdailynews.com/173-uighur-refugees-arrivein-turkey-from-thailand.aspx?pageID $=238 \& n I D=84912 \& N e w s C a t I D=359 /$. Accessed 18.12.2015.

Ikizoglu Erensu, A. and Kaşl1, Z. (2017) “A Tale of Two Cities: Multiple Practices of Bordering and Degrees of 'Transit' in and through Turkey" Journal of Refugee Studies 29(4): 528-548.

Ilgit, A, \& Davis, R. (2013). "The Many Roles of Turkey in the Syrian Crisis". Middle East Research and Information Project, http://ns2.merip.org/mero/mero012813. Accessed 16 December 2015

IOM (2014). Turkey Supports IOM Aid to Rohingya Migrants Detained in Southern Thailand, available at, http://www.iom.int/news/turkey-supports-iom-aidrohingya-migrants-detained-southern-thailand. Accessed on 17.12.2015.

IOM (2015). IOM, UNHCR Philippines Acknowledge Humanitarian Support from Government of Turkey, available at, http://www.iom.int/news/iom-unhcrphilippines-acknowledge-humanitarian-support-government-turkey. Accessed on 17.12.2015.

Kır, M. A Reconsideration of Turkey's Geographical Limitation to 1951 Geneva Convention, Hacettepe University Master Thesis, 2017 
Kipgen, N. "Conflict in Rakhine State in Myanmar: Rohingya Muslims' Conundrum" Journal of Muslim Minority Affairs 33(2016): 298-310.

Korkut, U. (2014) The Migration myth in the Absence of Immigrants: How does the conservative right in Hungary and Turkey grapple with immigration? Comparative European Politics 12: 620-636.

Korkut, U., Mahendran, K., Bucken-Knapp, G. and Cox, R. H. (eds.) (2015) Discursive Governance in Politics, Policy and the Public Sphere. New York: Palgrave Macmillan, Palgrave MacMillan, New York.

Kösebalaban, H. (2014) "Muslim Perceptions of Injustice as an International Relations Question", Perceptions XIX: 19-42.

Law on Foreigners and International Protection (2016), available at, http://www.refworld.org/cgi-bin/texis/vtx/rwmain?docid=5a1d828f4

Landau, L. B. "Wither Policy? South African Perspectives on Understanding Law, Refugee Policy and Protection." Journal of Refugee Studies 27(4): 534-552.

Leudar, I. and J. Nekvapil. "Media dialogical networks and political argumentation". Journal of Language and Politics 32 (2004): 247-266.

Linell, P. "Discourse across boundaries: On recontextualizations and the blending of voices in Professional discourse." Text \& Talk 18 (1998): 143-157.

Lu J., J. Aldrich, and S. Tianjian. "Revisiting Media Effects in Authoritarian Societies". Politics \& Society 42 (2014): 253-283.

MFA (2012) "Speech Delivered by Mr. Ahmet Davutoğlu, Minister of Foreign Affairs of the Republic of Turkey at the UN Security Council, 30 August 2012, New York" (30 August), available at, http://www.mfa.gov.tr/speechdelivered-by-mr_-ahmet-davutoğlu_-minister-of-foreign-affairs-of-therepublic-of-turkey-at-the-un-security-council_30-august-2012_-newyork.en.mfa. Accessed on 26.05.2015.

MFA (2013) Address by Mr. Naci Koru, Deputy Minister of Foreign Affairs of Turkey to the Members of Chicago Council on Global Affairs, 17 April 2013, Ankara, available at, http://www.mfa.gov.tr/address-by-mr_naci-koru deputy-minister-of-foreign-affairs-of-turkey-to-the-members-of-chicagocouncil-on-global-affairs -17-a.en.mfa (17 April). Accessed 28.06.2017.

MFA (2015a) "Dışişleri Bakanı Çavuşoğlu Avrupa Rohingya Konseyi delegasyonunu kabul etti", available at, http://www.mfa.gov.tr/disisleri-bakani-cavusogluavrupa-rohingya-konseyi-delegasyonunu-kabul-etti.tr.mfa. (18 August) Accessed 17.12.2015

MFA. (2015b) "No: 160, 20 May 2015, Press Release Regarding the Delivery of Humanitarian Aid to the Rohingyas and Bengalis Stranded in the Andaman Sea", available at, http://www.mfa.gov.tr/no -160 -20-may-2015 -pressrelease-regarding-the-delivery-of-humanitarian-aid-to-the-rohingyas-andbengalis-stranded-in-the-andaman-sea.en.mfa. (20 May) Accessed 17.12.2015

MFA. (2016a) "Dışişleri Bakanı Çavuşoğlu'nun Myanmar'ı ziyareti”, available at, http://www.mfa.gov.tr/disisleri-bakani-cavusoglu nun-myanmar_iziyareti.tr.mfa (12-14 June) Accessed 28.06.2017.

MFA. (2016b), "Foreign Minister Çavuşoğlu's visit to Myanmar", available at, http://www.mfa.gov.tr/foreign-minister-cavusoglu_s-visit-to-myanmar.en.mfa (12-14 June) Accessed 28.06.2017

Mahendran, K. (2012). "Introducing four psychologies of unemployment and their implications for intervention" in Unemployment, Precarious Work, and Health, Kisselbach, T. and Mannila, S. (eds.): 53-71. Germany: Springer. 
Moscovici, S. The phenomenon of social representations. In: R. M. Farr \& S. Moscovici. eds., Social Representations (Cambridge: Cambridge University Press, 1984).

NTV (2015). "Gambiya Arakanlı Müslümanları kabul etmeye hazır olduğunu açıkladı", available at, http://www.ntv.com.tr/dunya/gambiya-arakanlimuslumanlari-kabul-etmeye-hazir-oldugunu-acikladi,qJhKQji3EyQH9800sw02w? ref=infinite. Accessed 17.12.2015.

Özerdem, A. (2015). "Turkey as a Rising Power: An Emerging Humanitarian Global Actor" in The New Humanitarians in International Practice, Sezgin and Dijkzeul (eds.), 64-82. London: Routledge.

Pacitto, J. and Fiddian-Qasmiyeh, E. (2013) "Writing the Other into Humanitarian Discourse. Framing Theory and Practice in South-South humanitarian responses to forced migration" Oxford Refugee Studies Centre, available at, https://www.rsc.ox.ac.uk/files/files-1/wp93-south-south-humanitarianismcontexts-forced-migration-2013.pdf.

Parlar Dal, E. and Oğuz Gök, G. (2014) "Locating Turkey as a 'Rising Power' in the Changing International Order: An Introduction" Perceptions XIX: 1-19

Radikal (2005), "Korkulan oluyor", 02 January available at, http://www.radikal.com.tr/haber.php?haberno=139097 (02 January). Accessed on 18.12.2015.

Records of Parliamentary debates, (2005), available at https://www.tbmm.gov.tr/develop/owa/tutanak g sd.birlesim baslangic?P4=1 3625\&P5=B\&page $1=7 \&$ page $2=7$ (03 February). Accessed 17.12.2015

Syria Regional Refugee Response (2018), available at, http://data.unhcr.org/syrianrefugees/country.php?id=224.

Sabah (2015) "Turkey sends ship to help Rohingya Muslims", available at, http://www.dailysabah.com/nation/2015/05/19/turkey-sends-ship-to-helprohingya-muslims (19 May). Accessed on 17.12.2015.

Schmidt, V. A. (2010) "Taking ideas and discourses seriously: Explaining change through discursive institutionalism as the fourth "new institutionalism", European Political Science Review 2: 1-25.

Schwartz, B., Y. Zerubavel, and B. M. Barnett. (1986) "The Recovery of Masada: A Study in Collective Memory". The Sociological Quarterly 27(2): 147-164.

Tank, P. (2015). Turkey as a humanitarian actor: the critical case of Somalia an Syria. Noref Norwegian Peace Building Resource Centre, March.

T24 (2015). "Erdoğan: D1ş ülkelerden mülteciler için dolar kürü olarak yardım aldık fakat vicdan kürü olarak almadık", 21 December, available at, http://t24.com.tr/haber/erdogan-dis-ulkelerden-multeciler-icin-dolar-kuruolarak-yardim-aldik-fakat-vicdan-kuru-olarak-almadik,321218. Accessed 31.03.2016.

TRT (n.d.). "Turkey offers help to Rohingya Muslims", available at, http://www.trtworld.com/turkey/turkey-offers-help-rohingya-muslims-2129. Accessed on 17.12.2015.

Ulusoy, O. and Battjes, H. (2017) Returned and Lost: What Happens After Readmission to Turkey?. Available at: https://www.law.ox.ac.uk/researchsubject-groups/centre-criminology/centrebordercriminologies/blog/2017/10/returned-and-lost (Accessed 09.03.2018).

Yaron, H.; Hashimshony-Yaffe, N.; and Campbell, J. (2013). "Infiltrators" or Refugees? An Analysis of Israel's Policy Towards African Asylum-Seekers." International Migration 51(4): 144-157. 
Wilson, E. (2011). "Much to be Proud of, Much to be Done: Faith-based Organizations and the Politics of Asylum in Australia" 24: 548-564.

Woods, A. and Sazak, O. (2016) Turkey's Approach to Peacebuilding: Principles, Policies and Practices. IPC-MERCATOR Policy Brief.

Zaman, T. (2016). Islamic Traditions of Refuge in the Crises of Iraq and Syria. New York: Palgrave Macmillan. 